\title{
REVITALISASI KAPASITAS GURUBAHASA INGGRIS DALAM AKTIVITAS PEMBELAJARAN REFLEKTIF BERBASIS TRANSCRIPT BASED-LESSON ANALYSIS (TBLA) DALAM PERENCANAAN PEMBELAJARAN (PLANNING)
}

\author{
Suardi $1^{*}$ \\ Rahmawati Upa ${ }^{2}$ \\ Reski Pilu ${ }^{3}$ \\ ${ }^{1}$ Akademi Teknologi Industri Dewantara Palopo \\ 2,3 Universitas Cokroaminoto Palopo \\ suardisalbon01@gmail.com ${ }^{1 *}$ \\ rahmawatiupa22@gmail.com ${ }^{21}$ \\ reskipilu.uncp@gmail.com ${ }^{3)}$
}

Kata Kunci: [Revitalisasi, Pembelajaran Reflektif, TBLA, Perancanaan Pembelajaran]

\begin{abstract}
Abstrak: kegiatan pendampingan ini dilakukan untuk meningkatkan kemampuan guru model dalam merancang kegiatan pelaksanaan pembelajaran refektif dengan berbasis pada transcript based- lesson analysis. Kegiatan ini dilakukan dalam bentuk pelatihan yang dilkukan dengan menggunakan pendekatan Lesson Study secara kolaboratif dan membuat perencanaan pembelajaran dalam bentuk chart. Dalam PKM ini, ada beberapa istilah yang baru dan merupakan penamaan pada media yang dipakai yaitu Memo Paper Moving adalah media dari kertas kecil yang berisi tentang jam dalam bentuk digital jam yang akan diberikan kepada setiap siswa dan paper yang berpindah - pindah dari siswa ke siswa yang lain hingga setiap siswa akan menyebutkan jam pada Memo Paper Moving tersebut. Dalam RPP ini selain Memo Paper Moving digunakan, Jam dinding juga digunakan sebagai media pengajaran, serta lembar Kerja. Sehingga Lesson Plan yang dibuat mengarahkan pada Student Centre.
\end{abstract}

\section{Pendahuluan}

Kegiatan pendampingan ini dilakukan untuk meningkatkan kemampuan seorang guru model dalam merancang kegiatan pembelajaran melalui kegiatan pembelajaran reflektif berbasis transcript based- lesson analisis dalam perencanaan pembelajaran, sehingga hal yang dilakukan pertama kali adalah pendampingan guru model dalam membuat perencanaan pembelajaran yang dilakukan yang bertujuan untuk meningkatkan lesson analisis yang dimiliki oleh guru model. Sehingga Rencana Pelaksanaan Pembelajaran juga harus dirancang sesuai dengan konsep pembelajaran reflektif berbasis Transcrip Based- Lesson Analysis (TBLA).

Amintarti (2020) menjelaskan bahwa model TBLA adalah salah satu model yang digunakan dalam Lesson Study Learning Community (LSLC) yang menganalisis pembelajaran melalui dialog antara guru dengan siswa, siswa dengan siswa atau 
percakapan yang dilakukan oleh siswa itu sendiri terhadap interaksi yang dilakukan pada media maupun hal yang terjadi secara spontanitas dalam proses pembelajaran berlangsung. Sehingga dari pernyataan ini juga dapat disimpulkan bahwa rencana pelaksanaan pembelajaran harus di desain dengan baik yang menimbulkan reaksi dari siswa atau guru.

Adapun guru model yang akan menjadi mitra dalam penelitian ini adalah guru yang pernah mengikuti Lesson Study dan sudah menjadi guru model. Adapun alas an untuk memilih guru model berdasarkan dengan kriteria perna menajdi guru model karena telah memimilki pengalaman dalam Lesson Study. Sehingga dalam pelaksanaan pembuatan perencanaan pelaksanaan pembelajaran guru model telah memiliki pemahaman tentang rencana pembelajaran secara kolaborasi dan membahas permasalahan pembelajaran secara berkolaborasi juga. Kegiatan ini masih memiliki keterkaitan dengan kegiatan Lesson Study yang dimana kegiatan akan dilakukan mulai dari Plan, Do dan See. Namun dalam pembahasan kali ini hanya berfokuskan pada kegiatan plan saja. Menurut Hendayana (2007) menjelaskan bahwa Lesson study adalah model pembinaan (pelatihan) profesi pendidik melalui pengkajian pembelajaran secara kolaboratif dan berkelanjutan berlandaskan prinsip-prinsip kolegialitas dan mutual learning untuk membangun komunitas belajar.

Perencanaan pelaksanaan pembelajaran merupakan skenario pembelajaran yang akan dilakukan. Suardi (2016) perencanaan pembelajaran atau lesson plan merupakan gambaran aktifitas antara pengajar dan pembelajar yang akan berlangsung didalam kelas pada saat proses pembelajaran berlangsung. Sehingga perencanaan pembelajaran harus dipikirkan dan direncanakan dengan baik. Perencanaan pembelajaran dalam Lesson Study dilakukan secara berkolaborasi untuk menghasilkan Rencana Pelaksanaan Pembelajaran yang baik.

Berdasarkan dengan panduan riset dari draft Pelaksanaan Kegiatan Riset Kompetitif Nasional Sekema Penelitian Dasar 2019: Dua hal penting yang ingin ditingkatkan berkenaan dengan kapasistas guru yaitu methods dan insight. Methoda pembelajaran meliputi pedagogy knowledge, content knowledge, pedagogy content knowledge. Metoda pembelajaran akan terlihat dalam rancangan (disain) pembelajaran atau ketika membelajarkan siswa. Apakah guru hanya menyampaikan informasi kepada siswa dengan ceramah dari awal sampai akhir pembelajaran?Apakah siswa difasilitasi untuk melakukan percobaan, diskusi kelompok, dan sharing temuan di kelas?Apakah tidak terjadi salah konsep materi ajar? Apakah pedagogi dan konten dipadukan dalam pembelajaran untuk membuat siswa enjoy belajar.

Insight merupakan hal-hal yang tidak nampak dalam rancangan pembelajaran, unpredictable, terjadi spontan dalam pembelajaran,dan guru harus mengambil keputusan (decision). Apabila kita terlalu banyak bicara dalam pembelajaran maka insight tidak akanterjadi. Insight terjadi ketika guru tidak banyak bicara tapi lebih banyak mengobservasi wajah-wajah siswa, satu persatu, boleh jadi kita menemukan seorang siswa yang kebingungan di belakang. Apa dibiarkan saja sampai berahirnya pembelajaran bingung terus? Guru yang punya naluri insightakan menghampiri pelan-pelan agar tidak terganggu, melihat pekerjaannya, menanya pelan-pelan, kemudian siswa tersebut akan menunjukan bagian yang dianggap sulit. Kita sebagai guru yang ingin semua siswanya maju, harus mengambil keputusan mau diapakan siswa ini. 
Tabel1. Indikator peningkatan kapasitas guru

\begin{tabular}{|c|c|c|c|c|}
\hline \multirow[b]{2}{*}{ Komponen } & \multicolumn{4}{|c|}{ Level kapasitas guru } \\
\hline & $\begin{array}{l}\text { A (melebihi } \\
\text { harapan) }\end{array}$ & $\begin{array}{c}\text { B (memenuhi } \\
\text { harapan dengan } \\
\text { level tinggi) }\end{array}$ & $\begin{array}{l}\text { C (memenuhi } \\
\text { harapan) }\end{array}$ & $\begin{array}{l}\text { D (tidak } \\
\text { memenuhi } \\
\text { harapan) }\end{array}$ \\
\hline $\begin{array}{l}\text { Pedagogy } \\
\text { Knowledge } \\
\text { (PK) }\end{array}$ & $\begin{array}{l}\text { Ceramah, kerja } \\
\text { mandiri, diskusi, } \\
\text { eksperimen }\end{array}$ & $\begin{array}{l}\text { Ceramah, kerja } \\
\text { mandiri, diskusi }\end{array}$ & $\begin{array}{l}\text { Ceramah dan } \\
\text { diskusi }\end{array}$ & eramah \\
\hline $\begin{array}{l}\text { Content } \\
\text { Knowledge } \\
\text { (CK) }\end{array}$ & $\begin{array}{l}\text { Benar, luas, } \\
\text { mendalam, aplikatif }\end{array}$ & $\begin{array}{l}\text { Benar, luas, } \\
\text { mendalam }\end{array}$ & Benar, luas & Salah konsep \\
\hline $\begin{array}{l}\text { Pedagogy } \\
\text { Content } \\
\text { Knowledge } \\
\text { (PCK) }\end{array}$ & $\begin{array}{l}\text { Dialog (guru-siswa- } \\
\text { siswa), kontekstual, } \\
\text { eksperiment, } \\
\text { sharing ide }\end{array}$ & $\begin{array}{l}\text { Dialog (guru- } \\
\text { siswa-siswa), } \\
\text { kontekstual, } \\
\text { eksperiment }\end{array}$ & $\begin{array}{l}\text { Dialog (guru- } \\
\text { siswa-siswa), } \\
\text { kontekstual }\end{array}$ & $\begin{array}{l}\text { Monolog } \\
\text { (guru-siswa), } \\
\text { tidak } \\
\text { kontekstual }\end{array}$ \\
\hline & $\begin{array}{l}\text { Sedikit bicara, peka } \\
\text { terhadap siswa, } \\
\text { membantu siswa } \\
\text { kurang, siswa enjoy }\end{array}$ & $\begin{array}{l}\text { Sedikit bicara, } \\
\text { peka terhadap } \\
\text { siswa, membantu } \\
\text { siswa kurang }\end{array}$ & $\begin{array}{l}\text { Sedikit bicara, } \\
\text { peka terhadap } \\
\text { siswa }\end{array}$ & $\begin{array}{l}\text { Banyak bicara, } \\
\text { tidak peka } \\
\text { terhadap } \\
\text { siswa }\end{array}$ \\
\hline \multicolumn{5}{|c|}{$\begin{array}{l}\text { Dasar inilah menjadi rujukan dalam pembuatan rencana pelaksanaan } \\
\text { pembelajaran yang di rencanakan. Selain penjelasan diatas, Pengembangan disain } \\
\text { pembelajaran lebih baik dilakukan secara kolaborasi beberapa guru dan dosen } \\
\text { dibandingkan secara mandiri karena sendirian merasa sudah baik tapi bila ada orang lain } \\
\text { memberi masukan akan menjadi lebih baik. Target luaran pada PKM ini berupa } \\
\text { Rancangan pembelajaran dalam bentuk Chartyang berisi tentang alur pembelajaran yang } \\
\text { dibuat dalam satu kertas. }\end{array}$} \\
\hline
\end{tabular}

\section{Metode Pelaksanaan}

Kegiatan pengabdian ini dilakukan dalam bentuk pelatihan dan pendampingan dalam pembuatan Rencana Pelaksanaan Pembelajaran yang dilakukan di SMP Cokroaminoto Palopo yang dikususkan kepada satu guru saja yaitu guru pendidikan Bahasa Inggris yang dipilih karena guru tersebut pernah menjadi guru model dan merupakan syarat dalam pembelajaran reflektif berbasis TBLA ini. Kegiatan ini dilakukan mulai dari tanggal 20 Srtember - 20 Oktober 2019. Langkah - Langkah Kegiatan PKM:

1. Memberikan Pelatihan tentang TBLA yang dihubungkan dengan kegiatan Lesson Study

2. Melakukan kegiatan Lesson Study mulai dari kegiatan Plan, Do dan See

3. Pembuatan full transcript hasil pembelajaran

4. Menganalisis hasil pembelajaran dengan menggunakan TBLA

Namun dalam pembahasan ini kami hanya memfokuskan pada kegiatan pendampingan saat pembuatan perencanaan pembelajaran atau kegiatan Planning.

\section{Hasil dan Pembahasan}

Kegiatan ini diadakan pada hari jum'at, 20 September 2019 pukul 08.30 - 11.30 di ruang perpustakaan SMP Cokroaminoto Palopo, diikuti oleh empat Dosen, satu guru dan empat mahasiswa. Materi pelajaran yang di bahas adalah Time khususnya pada sub materi ajar tentang penyebutan Jam pada kelas VII (Tujuh). Guru model menyebutkan beberapa kendala terhadap siswa yang akan di hadapi, dimana siswa- siswa tersebut 
hampir tidak memiliki dasar dalam bahasa Inggris, oleh karena itu di putuskan untuk membuat desain pembelajaran yang dimulai dengan pengecekan pengetahuan siswa tentang Number. Dalam pengecekan pengetahuan ini, jika siswa memeliki kesulitan tentang Number maka guru akan melakukan tindakan yang berupa pengulangan atau Drilling dalam mengajarkan numbering ini, dengan menggunakan teman terlebih dahulu untuk membantu teman yang belum mengerti atau tahu tentang Number. Dalam mengecek pengetahuan siswa tentang Number guru meminta siswa secara berurutan menyebutkan nomor dalam bahasa Inggris sesuai tempat duduk mereka. Model tempat duduk yang digunakan adalah model bentu "U".

Muhammad (2012) menjelaskan bahwa pada umumnya siswa memberikan sikap positif terhadap pembelajaran yang menerpakan formasi tempat duduk model "U" hal ini berdasarkan dengan penelitian yang dilakukan pada kelas VII dengan memberikan agket skala sikap terhadap pembelajaran. Selain itu juga konsep formasi tempat duduk model "U" ini memang sering digunakan dalam kegiatan Lesson Study.

Setelah diyakini siswa mampu menghitung dalam bahasa Inggris Maka guru Model melanjutkan materi dengan bertanya What Time is It? Dalam pertemuan ini ada beberapa istilah yang baru dan merupakan penamaan pada media yang dipakai yaitu Memo Paper Moving adalah media dari kertas kecil yang berisi tentang jam dalam bentuk digital jam yang akan diberikan kepada setiap siswa dan paper akan berpindah - pindah dari siswa ke siswa yang lain hingga setiap siswa akan menyebutkan jam pada Memo Paper Moving tersebut. Dalam pengajaran ini selain Memo Paper Moving yang akan digunakan, Jam dinding juga akan digunakan sebagai media pengajaran, serta lembar Kerja. Untuk gambaran rencana pelaksanaan pembelajaran (RPP) sebagai berikut:

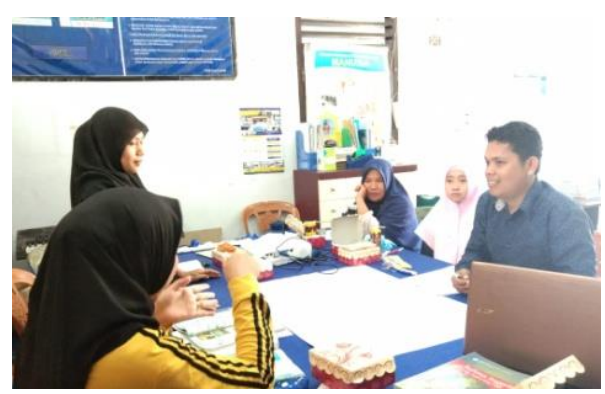

Gambar 1. Guru model menjelskan keadaan kelas, siswa dan materi yang akan diajarkan

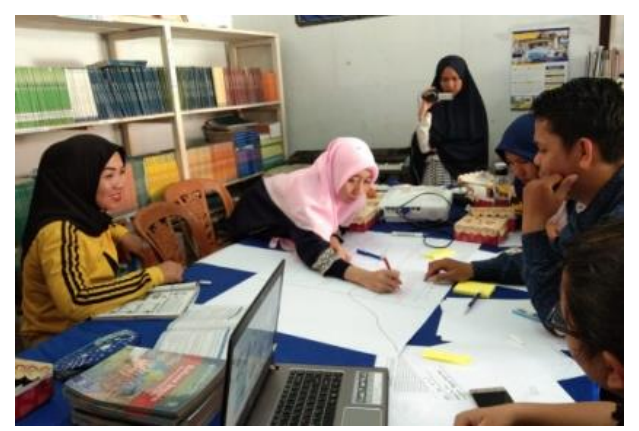

Gambar 2. Memberikan masukan dalam chart rencana pelaksanaan pembelajaran 


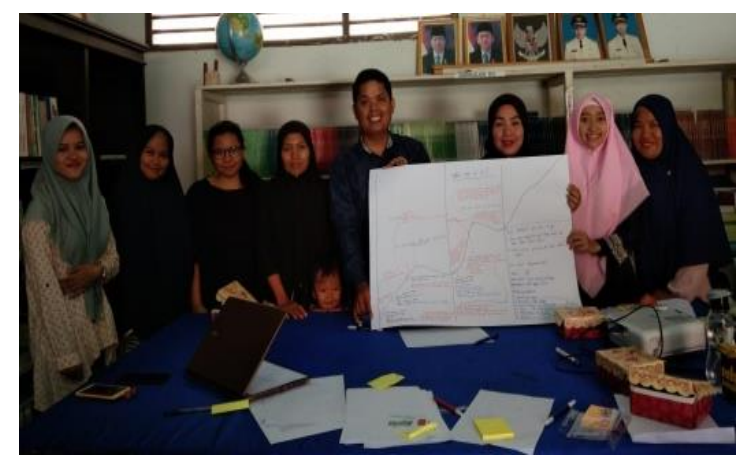

Gambar 3. Chart rencana pelaksanaan pembelajaran telah dikerjakan

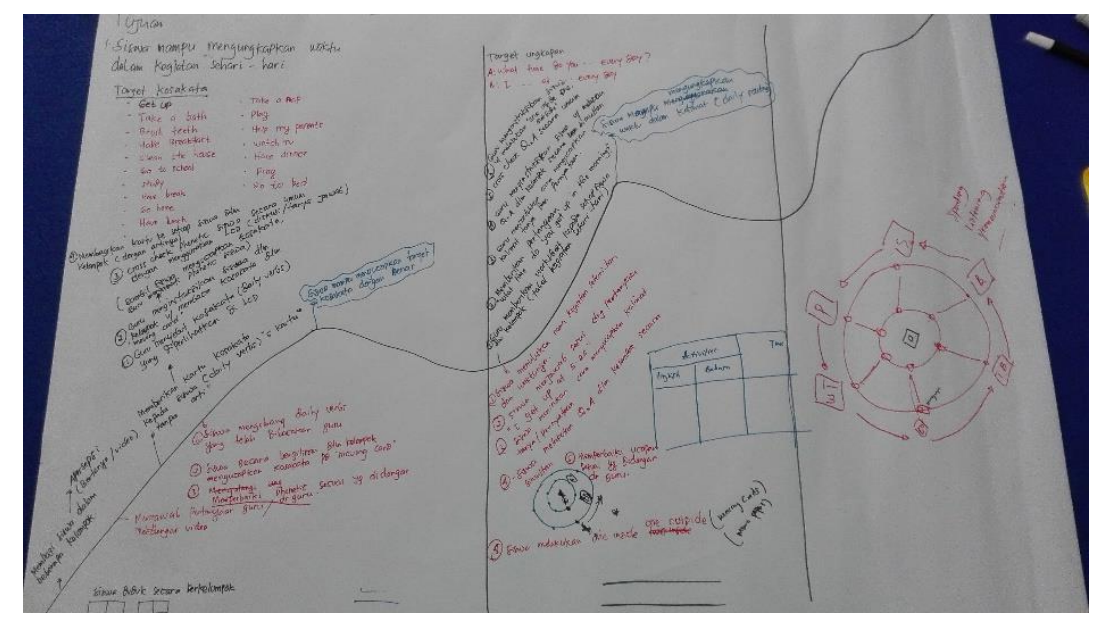

Gambar 4. Hasil dari chart rencana pelaksanaan pembelajaran

Setelah dibuatkan chart maka disipulkan dalam bentuk seperti dibawah ini:

\section{RENCANA PELAKSANAAN PEMBELAJARAN (RPP)}

$\begin{array}{ll}\text { Kelas / Semester } & \text { : VII } 1 \\ \text { Topik } & \text { : Time } \\ \text { Sub Topik } & \text { : What time is it? } \\ \text { Alokasi waktu } & : 2 \times 40 \text { menit }\end{array}$

Kompetensi Dasar : Menyusun teks interaksi transaksional lisan dan tulis sangat pendek dan melibatkan tindakan member dan meminta informasi terkait nama, hari, bulan, nama waktu dalam hari, waktu dalam bentuk angka, tanggal, dan tahun dengan fungsi sosial, strutur teks, dan unsur kebahasan yang benar dan sesuaikan konteks.

Tujuan pembelajaran : Siswa mampu menyebutkan dan menulisakan jam dalam bahasa inggris

\begin{tabular}{|c|c|c|}
\hline Prediksi Respon Siswa & Bantuan/ antisipasi guru & $\begin{array}{c}\text { Waktu } \\
\text { (menit) }\end{array}$ \\
\hline $\begin{array}{l}\text { Menjawab salam dari guru } \\
\text { "walaikumussalam } \\
\text { warahmatullahi wabarakatuh. } \\
\text { Siswa berdoa. } \\
\text { Model tempat duduk siswa } \\
\text { berbentuk "U" }\end{array}$ & $\begin{array}{l}\text { Guru mengucapkan } \\
\text { "AssalamualaikumwarahmatullahiWabarakatuh" } \\
\text { dan meminta ketua kelas untuk memimpin doa }\end{array}$ & 5 \\
\hline
\end{tabular}




\begin{tabular}{|c|c|c|}
\hline \multicolumn{2}{|c|}{ Silahkan berhitung dalam bahasa inggris ? } & \multirow[b]{2}{*}{10} \\
\hline $\begin{array}{l}\text { Siswa mulai berhitung secara } \\
\text { bergilir dan setiap siswa akan } \\
\text { mendapatkan giliran berhitung } \\
\text { sesuai dengan posisi tempat } \\
\text { duduk mereka. Nomor } 1 \\
\text { sampai dengan } 60 \text { dan jumlah } \\
\text { siswa } 20 \text { orang. } \\
\text { Siswa A: Saya tidak bisa ibu } \\
\text { guru. } \\
\text { Siswa B: hanya terdiam saja } \\
\text { tidak mampu menyebutkan } \\
\text { nama angka dalam bahasa } \\
\text { inggris. } \\
\text { Siswa C: saya ibu guru bisa } \\
\text { membantu "Five" }\end{array}$ & $\begin{array}{l}\text { Anak - anak sebelum kita memasuki materi hari } \\
\text { ini saya menginginkan kalian bisa menghitung } \\
\text { dalam bahasa inggris, jadi ibu mau tau dulu } \\
\text { apakah kalian sudah bisa menghitung dalam } \\
\text { bahasa inggris. } \\
\text { Jika terdapat siswa yang tidak bisa menyebutkan } \\
\text { angka dalam bahasa inggris maka guru } \\
\text { memberikan bantuan dengan "apakah ada yang } \\
\text { tau nama, tolong bantu temanya? }\end{array}$ & \\
\hline \multicolumn{2}{|r|}{ What time is it? } & \\
\hline $\begin{array}{l}\text { Siswa A,B,C : jam Sembilan bu } \\
\text { (Benar tetapi masih } \\
\text { menggunakan bahasa) } \\
\text { Siswa D : menjawab dalam } \\
\text { bahasa inggris akan tetapi } \\
\text { masih perlu bantuan dalam } \\
\text { memperbaiki penyebutanya } \\
\text { atau belum mengenal istilah - } \\
\text { istilah yang digunakan dalam } \\
\text { penyebutan jam } \\
\text { Semua siswa : terdiam tanpa } \\
\text { ada jawaban }\end{array}$ & $\begin{array}{l}\text { Guru memberikan bantuan dengan menjelaskan } \\
\text { istilah- istilah yang ada pada penyebutan jam } \\
\text { seperti (Past, to, half, quarter, dan clock) } \\
\text { Memberikan contoh dengan menggunakan jam } \\
\text { dinding }\end{array}$ & 10 \\
\hline Contoh memo paper & $\begin{array}{l}\text { Setelah guru memprediksi bahwa siswa sudah } \\
\text { bisa maka guru kembali memberikan latihan } \\
\text { dengan membagikan memo paper yang berisi } \\
\text { waktu sesuai jumlah siswa yang dan setiap siswa } \\
\text { akan mendapatkan waktu yang berbeda - beda. }\end{array}$ & 10 \\
\hline
\end{tabular}




\begin{tabular}{|c|c|c|}
\hline $\begin{array}{l}\text { Setiap siswa akan } \\
\text { menyebutkan jam pada memo } \\
\text { paper yang didapatkan. Dan } \\
\text { memo paper yang di dapatkan } \\
\text { akan berganti ganti sesuai } \\
\text { dengan perintah dari guru } \\
\text { ketika berkata Move. } \\
\text { Siswa A: maaf bu saya tidak } \\
\text { bisa/ diam/ salah pengucapan? }\end{array}$ & $\begin{array}{l}\text { What time is it? } \\
\text { Setiap guru berkata "move", maka memo paper } \\
\text { dipindahkan ke teman yang ada di samping } \\
\text { kanan } \\
\text { Apabila terdapat siswa yang mengalami kesulitan } \\
\text { maka guru akan meminta siswa yang lain untuk } \\
\text { membantu temanya. } \\
\text { Kenapa na' apa yang bisa di bantu? Adakah } \\
\text { teman yang bisa membantu menyebutkan jam } \\
\text { berapa yang tertulis di kertas "A"? } \\
\text { Terima kasih }\end{array}$ & 10 \\
\hline \multicolumn{3}{|c|}{ Apakah ada yang bisa menuliskan jam dalam bahasa inggris? } \\
\hline $\begin{array}{l}\text { SS : tidak ada yang bisa } \\
\text { menuliskan dengan benar } \\
\text { SS: semua siswa bisa } \\
\text { Siswa B : menulis dengan tepat } \\
\text { dan benar } \\
\text { Siswa C: saya bisa } \\
\text { memperbaiki pekerjaan si A }\end{array}$ & $\begin{array}{l}\text { Guru menempel memo paper di papan tulis } \\
\text { sambil bertanya apakah ada yang bisa } \\
\text { menuliskan } \\
\text { Jika semua siswa mapu menuliskan jawaban } \\
\text { dengan benar maka guru langsung memberikan } \\
\text { lembar Kerja } \\
\text { Jika sebagian siswa mampu maka guru meminta } \\
\text { siswa yang lain membantu teman yang belum } \\
\text { bisa } \\
\text { Jika tidak ada yang bisa maka guru memberikan } \\
\text { pocket dictionary kepada siswa sebagai bantuan }\end{array}$ & 10 \\
\hline \multicolumn{3}{|c|}{ Silahkan kerjakan lembar kerja! } \\
\hline $\begin{array}{l}\text { SS: mengerjakan LK selama } 10 \\
\text { menit } \\
\text { SS: siswa bertukar jawaban } \\
\text { SS: siswa mampu } \\
\text { mengkomunikasikan jawaban } \\
\text { dan mampu melihat }\end{array}$ & $\begin{array}{l}\text { Guru meminta siswa untuk mengerjakan LK } \\
\text { Guru menginstruksikan ke siswa untuk bertukar } \\
\text { jawaban } \\
\text { Guru memperlihatkan jawaban yang benar } \\
\text { dipapan tulis } \\
\begin{array}{l}\text { Guru meminta ke siswa untuk } \\
\text { mengkomunikasikan hasil koreksian ke siswa } \\
\text { agar menyampaikan ke teman dimana letak } \\
\text { kesalahanya pada lembar jawaban }\end{array}\end{array}$ & 15 \\
\hline SS: menjawab pertanyaan guru & $\begin{array}{l}\text { Guru memberikan penguatan dengan } \\
\text { memberikan pertanyaan "What time is it ?" } \\
\text { kepada siswa } \\
\text { Menyimpulkan pelajaran }\end{array}$ & 5 \\
\hline & Guru menutup pelajaran & 5 \\
\hline
\end{tabular}




\section{Kesimpulan}

PKM ini memberikan kontribusi yang sangat signifikan terhadap pembuatan perancangan pembelajaran. Dalam PKM ini, ada beberapa istilah yang baru dan merupakan penamaan pada media yang dipakai yaitu Memo Paper Moving adalah media dari kertas kecil yang berisi tentang jam dalam bentuk digital jam yang akan diberikan kepada setiap siswa dan paper yang berpindah - pindah dari siswa ke siswa yang lain hingga setiap siswa akan menyebutkan jam pada Memo Paper Moving tersebut. Dalam RPP ini selain Memo Paper Moving digunakan, Jam dinding juga digunakan sebagai media pengajaran, serta lembar Kerja. Sehingga Lesson Plan yang dibuat mengarahkan pada Student Centre.

\section{Ucapan Terimakasih}

Kegiatan ini dapat terlaksana berkat kerjasamaantara dan dukungan dari beberapa pihak. Kami ingin mengucapkan terima kasih kepada ALSI (Asosiasi Lesson Study Indonesia dan ICLI (Indonesia Consortium for Learning Improvement) yang telah memberikan dukungan berupa materi dan dukungan untuk megikutkan kami dalam pendampingan pada penelitian ini sehingga pengabdian ini dapat terlaksana dalam mendampingi guru model. Kepada Universitas Cokroaminoto Palopo dan Fakultas Keguruan dan Ilmu Pendidikan UNCP, serta sekolah mitra SMP Cokroaminoto Palopo sebagai tempat pendampingan dalam hal ini kepala sekolah dan terkhusus kepada ibu Nurjannah, S.Pd.I. selaku guru model yang siap didampingi dalam pelaksanaan TBLA ini. Serta teman-teman Program Studi Pendidikan Bahasa Inggris UNCP yang telah membantu dalam pelaksanaan siklus Lesson Study berlangsung di sekolah mitra selama pendampingan.

\section{Referensi}

S. Amintarti, A. Winarti, A Sholahuddin, S. Syahman. (2020). Penerapan Transcript Based Lesson Analysis (TBLA) sebagai Upaya Peningkatan Pembelajaran Kimia. Quantum: Jurnal Inovasi Pendidikan Sains, 11 (2), 149-163. Retrieved from https://ppjp.ulm.ac.id/journal/index.php/quantum/article/view/8219

Hendayana, S. d. (2007). Lesson Study Suatu Strategi Untuk Meningkatkan keprofesionalan Pendidik. Bandung: FPMIPA UPI dan JICA.

Muhammad, G. M., dan Andriani, S. (2012). Pengaruh Formasi Tempat Duduk Model U Terhadap Pemahaman Konsep Siswa SMP pada Pokok Bahasan Himpunan. Jurnal Kependidikan, 13(18), 65-76.

Suardi, S. (2016). Aktifitas mahasiswa dalam lesson study pada pmbelajaran English Learning Media. Prosiding Seminar Nasional, 2(1), 587-598. Retrieved from https://journal.uncp.ac.id/index.php/proceding/article/view/648 